\title{
Nomeações políticas no Ministério do Meio Ambiente (2003-2013): interconexões entre ONGs, partidos e governos
}

Rebecca Neaera Abers

Marília Silva de Oliveira

\section{Introdução ${ }^{1}$}

Em 11 de dezembro de 2002, poucas semanas antes de assumir o cargo de presidente da República, Luiz Inácio Lula da Silva anunciou que a renomada ativista ambiental Marina Silva seria ministra do Meio Ambiente em seu governo. O anúncio ocorreu em Washington, Estados Unidos, pouco antes de Lula se reunir com George W. Bush, o então presidente daquele país.

Marina Silva nasceu e se criou numa comunidade de seringueiros no Acre. Ela militou ao lado de Chico Mendes, cujo assassinato em 1988 chamou a atenção do mundo inteiro para a luta do movimento seringueiro no Acre. Exerceu o cargo de deputada estadual de 1991 a 1994 e, nesse último ano, foi eleita senadora pelo seu estado, representando o Partido dos Trabalhadores (PT). Na gestão do presidente Fernando Henrique Cardoso (de 1995 a 2002), foi líder do PT no Senado e líder do bloco de todos os partidos da oposição. Em 1996, foi reconhecida internacionalmente com o Prémio Goldman de Meio Ambiente pela América Latina e Caribe. Nas eleições de 2002, Marina foi reeleita senadora, mas se licenciou do cargo para assumir o posto de ministra do Meio Ambiente.

A nomeação de Marina foi uma agradável surpresa para os ambientalistas, muitos dos quais participaram de uma campanha nacional liderada por algumas organizações não governamentais (ONGs) logo após a eleição de Lula para presidente. A campanha propunha o nome de Marina Silva para assumir a liderança do Ministério do Meio Ambiente. A senadora havia sido importante representante dos ambientalistas no Congresso Nacional e também exercia grande influência no PT. Ela era uma liderança no

\footnotetext{
${ }^{1}$ As autoras agradecem ao Instituto de Pesquisa Econômica Aplicada pela disponibilização de base de dados que possibilitou a realização da pesquisa e aos pareceristas anônimos pelos comentários que contribuíram para a melhoria do texto.
} 
seu partido e também no movimento ambientalista, especialmente para aqueles que defendiam a perspectiva socioambientalista.

Essa "dupla cidadania" Ihe concedeu influência em ambos os campos, uma vez que a senadora tinha conexões e prestígio tanto no partido quanto no movimento. Mas essa condição também seria fonte de tensões quando se tornou ministra. Se, por um lado, os líderes do partido solicitavam que ela mantivesse o movimento ambientalista sob controle, por outro, os ativistas ambientalistas pressionavam para que conseguisse concessões do partido. Apesar dessas complexidades, os ambientalistas tinham grandes expectativas em Marina como ministra, o que também espelhava a euforia generalizada dos movimentos sociais brasileiros com Lula na presidência. Quando Lula foi finalmente eleito, após três derrotas em campanhas presidenciais, movimentos sociais diversos passaram a trabalhar próximos aos tomadores de decisões governamentais e muitos, de fato, aceitaram empregos no governo.

Contudo, desde que o PT assumiu a presidência, a relação entre o partido e os movimentos sociais mudou. Na área ambiental, a mudança foi particularmente dramática. Após Marina deixar o ministério durante a segunda gestão de Lula na presidência, a senadora também abandonou o PT. Em 2010, ela concorreu a eleições presidenciais por outra legenda partidária e hoje é membro da oposição. Marina foi acompanhada por um grupo de ativistas ambientais que expressam uma crescente frustração com o atual governo.

Neste artigo, exploramos as mudanças nas relações entre movimentos sociais e o governo do PT pelas lentes da política de nomeações de cargos de alto escalão no Ministério do Meio Ambiente (MMA). O estudo gira em torno das biografias profissionais e políticas de 147 indivíduos nomeados a cargos de confiança, DAS 6 (secretários) e DAS 5 (diretores), no Ministério do Meio Ambiente entre os anos 2003 e $2013^{2}$. Conduzimos buscas na internet a fim de obter informações sobre as experiências profissionais de cada nomeado a esses cargos. Procuramos particularmente por informações sobre suas experiências anteriores em ONGs e em outras organizações da sociedade civil, bem como por outros tipos de experiência educacional e profissional. Uma vez que as pessoas analisadas assumiram posições de destaque no governo federal, tivemos bastante êxito em encontrar informações sobre elas na internet ${ }^{3}$. Nós também incluímos no banco de dados informações sobre a filiação partidária dos nomeados, com o objetivo de identificar aqueles que eram membros do PT no momento

\footnotetext{
2 Os dados sobre nomeados a cargos de confiança entre 2003 e 2012 foram concedidos pelo Instituto de Pesquisa Econômica Aplicada (Ipea). As informações sobre os nomeados a cargos DAS 5 e 6 no MMA ao longo de 2013 foram encontradas por meio de busca na seção 2 do Diário Oficial da União. Apesar de os secretários executivos assumirem cargos de natureza especial (NE), neste artigo, eles foram alinhados junto aos secretários (DAS 6), organizando todos os secretários em uma única categoria.

${ }^{3}$ A pesquisa na internet foi conduzida, na maior parte, por um conjunto de estudantes de graduação em ciência política, com três estudantes responsáveis em cada ano e trabalhando separadamente para maximizar a qualidade da informação.
} 
de sua nomeação. Na intenção de dar mais sentido a esses dados, conduzimos 23 entrevistas com pessoas que trabalharam no Ministério ou que as acompanharam durante esses 11 anos do período coberto pela pesquisa.

Conforme abordaremos nas páginas seguintes, os dados sobre nomeações mostram significativas mudanças no perfil dos indivíduos que assumiram cargos DAS 5 e 6 no MMA durante a gestão dos três ministros que chefiaram o ministério desde que o PT assumiu a presidência do Poder Executivo: Marina Silva (de 2003 a 2008), Carlos Minc (de 2008 a 2010) e Izabella Teixeira (de 2010 até agora). O artigo busca explicar a mudança no perfil dos nomeados aos cargos de alto escalão no MMA como reflexo de mudanças nas relações entre o governo do Partido dos Trabalhadores, a sociedade civil e a burocracia estatal. Sugerimos que as alterações no padrão das nomeações do Ministério do Meio Ambiente refletem um processo mais amplo de aproximação do party in public office (Katz e Mair, 1993, 1995) da burocracia estatal - um resultado que envolve tanto transformações de preferências políticas da liderança do governo como a mudança em sua capacidade de tomada de decisões, que se tornou menos vinculada à sociedade civil ao longo do tempo.

Na próxima seção ("As nomeações políticas e a sociedade civil") exploramos os debates recentes sobre política de nomeações a cargos de confiança no governo federal e sobre a relação entre movimentos sociais e o governo federal do PT. As seções seguintes ("A política ambiental federal antes do governo PT" e "As três administrações petistas do MMA") trazem um histórico sobre a política ambiental no Brasil e as dinâmicas políticas dos três ministros do Meio Ambiente na era petista. Na sequência ("As trajetórias profissionais e as políticas dos nomeados"), apresentamos a análise dos dados coletados sobre os nomeados a cargos DAS 5 e DAS 6 no MMA de 2003 a 2013. Por fim, a seção "A transformação da relação entre Estado e sociedade civil na era petista" finaliza o artigo com uma discussão sobre como o exame das alterações nos padrões de nomeações a cargos políticos estratégicos no governo federal pode nos auxiliar a entender mudanças nos padrões de relações entre Estado e sociedade civil ao longo do tempo, especialmente quando um partido historicamente vinculado a movimentos sociais passa mais de uma década na presidência da República.

\section{As nomeações políticas e a sociedade civil}

Nomeações para cargos da burocracia são tipicamente analisadas como um dos principais recursos de divisão de poder no governo (Lopez, Bugarin e Bugarin, 2013). Contudo, compreender por que o presidente e seus ministros nomeiam determinadas pessoas e quais elementos indicam quem vai ocupar os cargos mais estratégicos é tarefa complicada. Para alguns, analisar a política de nomeação de cargos públicos de determinado governo pode significar o mesmo que investigar relações de patronagem 
partidária (De Winter, 2006), que serve a diferentes propósitos. No esquema elaborado por Scherlis (2009), as nomeações podem atender a distintas funções, como objetivos eleitorais e fortalecimento da estrutura organizacional do partido; e pode servir a propósitos governamentais no sentido de o partido no governo controlar determinadas instituições e políticas públicas e, dessa forma, vir a implementar um governo partidário ${ }^{4}$.

A fim de evitar esquemas de patronagem na ocupação de cargos públicos, relações clientelistas e a consequente ineficiência burocrática, Geddes (1990) defendeu a necessidade de burocratas estáveis e técnicos assumirem o processo de tomada de decisão nas agências públicas a ponto de insulá-las dessa prática considerada daninha para a administração pública. Todavia, esse argumento é contraposto pela literatura que enxerga na política de ocupação de cargos públicos uma ferramenta para viabilizar o presidencialismo de coalizão, como uma forma de o partido no governo partilhar poder com os partidos de sua base aliada no parlamento (Raile, Pereira e Power, 2011).

A depender da estratégia adotada pelo governo para nomeações a cargos da administração pública, Loureiro, Olivieri e Martes (2010) observaram que ele pode se ver diante de um dilema: angariar apoio no Congresso Nacional, mas debilitar a capacidade de eficiência de sua burocracia que estará a serviço de interesses partidários e não do interesse público comum; ou, por outro lado, pode enfatizar a capacidade tecnocrata da administração pública e prejudicar seu poder decisório por falta de apoio partidário de sua base aliada no parlamento. Portanto, é lançado ao presidente o desafio de equacionar tal dilema de forma a garantir tanto a eficiência e a efetividade de sua burocracia e das políticas públicas, bem como assegurar apoio político partidário para coordenar seu poder decisório (Loureiro, Olivieri e Martes, 2010). Nesse aspecto, há uma dicotomia na literatura entre duas explicações para as nomeações a cargos de alto escalão do governo.

Scherlis (2009) chama atenção para o fato de que nenhuma dessas lógicas decisórias é apolítica. O autor especifica quatro motivos diferentes, mas não excludentes, que podem orientar a seleção de nomeados: membros do partido, expertise, afinidade ideológica e relações pessoais. Para ele, todas essas práticas inclusive a escolha baseada em expertise técnica - são orientadas pelo desejo de o partido em comando do Poder Executivo garantir sua continuidade no poder.

No Brasil, a política de nomeações de cargos públicos já foi analisada a partir de diferentes perspectivas, tais como a influência de partidos políticos na burocracia (Lopez, Bugarin e Bugarin, 2013); o aumento da capacidade estatal em função da composição burocrática (Bersch, Praça e Taylor, 2013); os determinantes para a rotatividade de funcionários federais (Praça, Freitas e Hoepers, 2012); a análise do perfil dos burocratas (D'Araújo, 2009); e o controle que o presidente da República pode

\footnotetext{
${ }^{4}$ Ver Figueiredo (2010).
} 
exercer sobre a burocracia (Lameirão, 2011). A maioria desses estudos está atenta ao nível de politização da burocracia. No entanto, estudos como o de Praça, Freitas e Hoepers (2012), sobre a rotatividade dos ocupantes de cargos de confiança na administração pública, destacam que a dinâmica de ocupação desses cargos pode estar mais relacionada com questões burocráticas que valorizam a expertise política do que com orientações partidárias.

Uma lacuna existente na literatura sobre nomeações é quanto ao papel dos atores oriundos dos movimentos sociais entre os nomeados políticos. Ao considerar a história do PT, há boas razões para examinar a participação desse tipo de ator no governo petista. Diferente da maioria dos partidos brasileiros, o PT tem, desde a sua origem, uma forte proximidade com os movimentos sociais. Da sua fundação, participaram não somente lideranças do Novo Sindicalismo, como o próprio Lula, mas também uma diversidade de movimentos sociais - estudantis, urbanos, ambientais, de luta por mulheres, direitos humanos, saúde, e muitos outros (Keck, 1992; Meneguello, 1989). A organização do partido, nas décadas iniciais de sua formação, destoava daquela dos outros partidos brasileiros, por suas características bottom-up e pela importância na estrutura organizacional de secretarias setoriais ligadas diretamente aos movimentos (Ribeiro, 2008).

No entanto, Ribeiro (2008, 2014) argumenta que, entre 1980 e 2012, ocorreu uma aproximação do partido ao Estado ao mesmo tempo em que houve um distanciamento dos movimentos sociais. O autor mostra que o partido se tornou cada vez mais dependente do Estado em termos financeiros com a crescente importância do fundo partidário e das contribuições obrigatórias para as receitas partidárias de pessoas nomeadas a cargos governamentais (Ribeiro, 2014). Também mostra que os quadros partidários eram cada vez mais compostos por funcionários estatais. A parcela dos delegados nos Encontros Nacionais do PT que tinham cargo comissionado no Legislativo ou no Executivo subiu de $11 \%$ em 1990 para 24\% em 2006. No mesmo período, houve um forte declínio da parcela de profissionais ligados a movimentos sociais e sindicatos (Ribeiro, 2008, p. 141). Para Ribeiro, a implicação desse feito é clara: ocorreu o processo clássico, previsto há um século por Michels, de oligarquização do partido e de distanciamento das elites partidárias dos militantes de massa.

Embora Ribeiro demonstre a crescente proximidade do partido ao Estado de forma bastante convincente, a tese de distanciamento simultâneo da sociedade civil é mais ambígua. Como mostra Amaral (2011, p. 31-32), a afirmação de Ribeiro é colocada em xeque pelas declarações dos próprios delegados nos Encontros Nacionais do partido, uma vez que uma parcela relativamente estável, em torno de $70 \%$ de delegados, declarou ao longo do tempo participar de movimentos e organizações sociais. O próprio Ribeiro reconhece a ambiguidade, sugerindo que o enfraquecimento do vínculo com a sociedade civil não foi severo e acrescenta que, apesar de cada vez 
mais adaptado ao terreno do Estado, o PT permanece navegando nas águas da sociedade civil como um partido anfíbio (Ribeiro, 2014, p. 117).

No primeiro governo Lula, a proximidade entre o PT e os movimentos sociais se revelou como sendo significativa: ocorreu um incremento forte da presença de movimentos sociais em cargos comissionados. O estudo de Maria Celina D'Araújo mostra, por exemplo, que $45 \%$ dos nomeados a DAS 5 e DAS 6 no primeiro governo Lula e $43 \%$ dos nomeados no segundo governo eram filiados a sindicatos. Uma parcela ligeiramente maior declarou ter participado de movimentos sociais (D'Araújo, 2009, p. 53). Estudos mais qualitativos como os de Abers, Serafim e Tatagiba (2014), Serafim (2013) e Losekann (2009) mostram o forte impacto que militantes de movimentos sociais tiveram nas políticas ao assumirem cargos-chave no primeiro governo Lula em áreas como Cidades, Desenvolvimento Agrário, Meio Ambiente.

A obra influente de Dagnino, Olvera e Panfichi (2006), inspirada por essas tendências, propõe um marco teórico para compreender o trânsito de ativistas entre sociedade e Estado, ao argumentar que atores de ambos os lados podem compartilhar projetos políticos. Diversos outros autores mais recentes, como Feltran (2006), Abers e Von Bülow (2011), Silva e Oliveira (2011), Tatagiba (2011), Tatagiba, Paterniani e Trindade (2012), Dowbor (2012) e Rich (2013) também analisaram os efeitos da migração de ativistas para o interior do Estado tanto no governo federal petista quanto no período anterior ou em governos municipais e estaduais.

Ao mesmo tempo em que há essas aproximações, sabemos que, desde o início do primeiro governo Lula, a relação entre o governo federal do PT e os movimentos sociais sofreu tensionamentos e, às vezes, rupturas. Já nos primeiros anos do governo, o descontentamento de atores ligados a movimentos de esquerda levou a rupturas importantes, como a saída de diversos líderes petistas para o recém-criado Partido Socialismo e Liberdade (PSOL), em 2005, após a decisão do governo do PT de apoiar a reforma da Previdência (Genro e Robaina, 2006). Alguns movimentos sociais, como o MST, criticaram a falta de compromisso do governo com suas causas, mesmo sem assumir um rompimento completo com o governo (Branford, 2009).

O escândalo do mensalão testou ainda mais as lealdades dos movimentos sociais e teve impactos duros em algumas áreas. O Ministério das Cidades foi a primeira vítima. A criação do ministério, em 2003, havia sido comemorada como uma grande conquista do Fórum Nacional de Reforma Urbana (FNRU), especialmente com a nomeação de Olívio Dutra, visto como aliado dos movimentos urbanos. Em julho de 2005, no entanto, o ministério foi entregue a Márcio Fortes, do conservador Partido Progressista (PP), na tentativa de reconstruir a coalizão governamental após o escândalo. Muitos militantes do FNRU e dos movimentos de moradia saíram do ministério junto com Dutra (Abers, Serafim e Tatagiba, 2014; Serafim, 2013). Como 
veremos a seguir, a saída de Marina Silva do MMA, em 2008, foi também associada com um processo de distanciamento entre o governo e um grupo de ONGs ambientalistas.

As duas dinâmicas políticas de nomeações discutidas na literatura acima mencionada - a de angariar apoio político e a de viabilizar tecnicamente a implementação de políticas públicas específicas - podem interagir de forma a diminuir o espaço no governo federal de atores ligados a movimentos sociais. Não temos dados que demonstrem se houve ou não uma diminuição generalizada do número de ativistas de movimentos sociais nomeados a cargos públicos ao longo do período petista no governo federal, pois os únicos dados quantitativos que investigam o assunto foram coletados no início do segundo governo Lula (D’Araújo, 2007, 2009).

Os relatos setoriais - Cidades e Meio Ambiente - sugerem duas razões centrais que poderiam explicar a saída de ativistas de cargos governamentais na medida em que isso de fato ocorreu. Por um lado, a lógica de nomeação político-partidária pode implicar a exclusão de determinados atores quando o governo reavalia sua importância relativa na construção de uma coalizão política. Por outro, mudanças em relação a quais políticas públicas o governo enxerga como necessárias para manter o apoio político também podem levar à autoexclusão de alguns atores, especialmente quando se trata de ativistas comprometidos com causas desvalorizadas.

Os dados apresentados mais adiante mostram não somente uma diminuição significativa da presença de ativistas de movimentos sociais em cargos comissionados de alto escalão no MMA, mas também de todas as outras categorias, com exceção de pessoas oriundas da própria burocracia federal. Com apoio não somente dos dados biográficos dos nomeados, mas também de entrevistas com atores envolvidos na política ambiental do período, concluímos que essa mudança resulta, em parte, dos dois fatores citados acima, quais sejam: houve uma reorientação de prioridades políticas e também mudanças na dinâmica de coalizão política.

Há, porém, uma terceira dimensão do processo de nomeação política que se relaciona com os recursos humanos aos quais um governo tem acesso para recrutar a cargos comissionados. Uma razão pela crescente presença de servidores públicos entre os nomeados pode ter a ver com o aumento do número de quadros qualificados na burocracia federal para lidar com questões ambientais. Ou seja, no período analisado, ocorreram mudanças não somente na dinâmica política, mas também na estrutura do Estado brasileiro, resultado em parte da política de fortalecimento da burocracia federal, com a criação da carreira ambiental e realização de concursos públicos, implementada pelo próprio governo petista (Cruz, 2010; Marconi, 2010; Cardoso J r., 2011).

Ao longo dos anos 2000, tornou-se maior o número de burocratas estáveis e capacitados na área ambiental e em áreas afins. Esse processo pode ter possibilitado a intensificação da aproximação entre o PT e o Estado detectada por Ribeiro (2008) no período anterior a 2003. Intencionalmente ou não, ao promover uma política de 
fortalecimento da burocracia, o governo do PT criou maiores condições para o crescente insulamento da tomada de decisão governamental, liberando-se de vínculos anteriores com atores da sociedade civil.

\section{A política ambiental federal antes do governo do PT}

Uma análise histórica da política ambiental brasileira demonstra claramente que os ambientalistas sempre construíram uma relação de proximidade com o governo federal. Isso não foi apenas uma peculiaridade do governo do Partido dos Trabalhadores. De fato, tal prática tem uma longa história nessa área de políticas públicas. O governo federal brasileiro começou a regulamentar os recursos naturais na década de 1930, na gestão de Getúlio Vargas, o líder autoritário conhecido por iniciar o esforço nacional para tornar o Brasil moderno e industrializado, baseado num conjunto de ideias conhecido como desenvolvimentismo (Franco, 2002; Drummond e BarrosPlatiau, 2006). Na década de 1950, alguns cientistas e burocratas com interesses profissionais sobre o meio ambiente criaram a organização não governamental Fundação Brasileira para a Conservação da Natureza (FBCN), no Rio de Janeiro, e se organizaram para influenciar o Estado. Para Alonso, Costa e Maciel (2007, p. 155),

a situação de funcionários públicos dos membros da FBCN deu-lhe desde sempre a feição de um grupo de interesse, procurando influir diretamente sobre as decisões de Estado, por meio de lobby, em detrimento de mobilizações públicas. Antes e durante o regime autoritário, essa estratégia foi bem-sucedida: a FBCN influenciou a criação de leis, órgãos e políticas ambientais e seus membros ascenderam aos cargos de direção na área. Nesse sentido, a trajetória de seus membros se confunde com a montagem da própria burocracia ambiental brasileira, dando à $\mathrm{FBCN}$ um caráter paraestatal até a década de 1970.

Em 1973, em resposta à Conferência das Nações Unidas para o Meio Ambiente Humano, que aconteceu no ano anterior em Estocolmo, Suécia, o governo brasileiro criou a Secretaria do Meio Ambiente (Sema), subordinada ao Ministério do Interior. Essa agência nasceu sob a influência direta dos institutos de pesquisa conservacionistas. Paulo Nogueira Neto, o primeiro secretário nacional de Meio Ambiente, era um renomado cientista naquele tempo e fundador da FBCN (Hochstetler e Keck, 2007).

Em 1981, ainda durante o período autoritário, a Política Nacional para o Meio Ambiente foi aprovada. Ela foi escrita quase que inteiramente pelos empregados da Sema (Viola e Leis, 1992; Drummond e Barros-Platiau, 2006) e foi considerada uma lei muito avançada para o seu tempo. Essa lei criou um dos primeiros conselhos participativos no Brasil, o Conselho Nacional de Meio Ambiente (Conama), e concedeu a este substancial autoridade para escrever e aprovar resoluções ambientais. A 
institucionalização de políticas ambientais naquele período também incluía várias ideias inovadoras, tais como o princípio de subsidiariedade, o licenciamento ambiental e os estudos de impacto ambiental (Drummond e Barros-Platiau, 2006).

Outro momento político crucial para o meio ambiente foi durante a Assembleia Constituinte de 1987. As organizações ambientalistas formaram uma coalizão para apoiar os membros da assembleia comprometidos a proteger o meio ambiente. Quinze por cento dos parlamentares da Assembleia Constituinte se inscreveram na Frente Parlamentar Verde, apta a redigir norma específica sobre o meio ambiente, que se tornou um artigo incluído na Constituição de 1988 (Hochstetler e Keck, 2007).

$\mathrm{Na}$ década de 1980, um novo tipo de narrativa ambiental, o socioambientalismo, começou a substituir o foco conservacionista do período anterior (Santilli, 2005; Viola e Vieira, 1992). Essa mudança era parcialmente o resultado das preocupações sociopolíticas que envolviam a abertura política, da percepção da importância dos povos da floresta para a preservação dos recursos naturais, da aproximação dos ambientalistas com partidos políticos, da capacidade de alguns ativistas brasileiros de mobilizar a atenção da comunidade internacional, especialmente sobre o desmatamento da Amazônia (Keck e Sikkink, 1998; Hochstetler e Keck, 2007).

Chico Mendes, líder do movimento dos seringueiros que lutou contra fazendeiros e grileiros que invadiam florestas amazônicas usadas para extração natural da borracha, era um importante ativista ambiental. Quando ele foi assassinado em 1988, sua morte publicizada largamente ajudou a disseminar a ideia de que os protetores da floresta sabiam como usar e proteger a floresta ao mesmo tempo. Marina Silva, que viria a ser ministra do Meio Ambiente sob o governo Lula, começou sua carreira política como parte do movimento liderado por Mendes.

Em 1992, a Conferência das Nações Unidas para o Meio Ambiente e Desenvolvimento, que ocorreu no Rio de Janeiro, foi crucial para promover a profissionalização e internacionalização de organizações ambientalistas brasileiras. A criação do Ministério do Meio Ambiente, em 1993, também foi consequência da Rio-92 e proveu os ambientalistas com um novo local institucional para direcionar suas ações. As principais atividades do ministério envolveram um programa com fundos internacionais para a proteção das florestas, o Programa Piloto para as Florestas Tropicais do Brasil, financiado pelo então grupo dos países mais industrializados do mundo, o G-7, que incorporou várias ideias socioambientalistas.

Esse programa, também conhecido por PPG-7, implementou projetos experimentais, como o agroflorestal, e criou reservas para o extrativismo sustentável dos produtos florestais, como borracha e castanhas brasileiras. Cada projeto tinha um conselho participativo ou comissão, e o programa proveu fundos diretos para apoiar a criação de uma organização guarda-chuva para a sociedade civil da Amazônia, o Grupo de Trabalho Amazônico, GTA (Abers et al., 2000). 
Durante o primeiro governo de Fernando Henrique Cardoso (1995-1998), o ministério se expandiu dramaticamente com a incorporação de um grande portfólio para projetos de irrigação, que objetivava fazer o ministério politicamente atrativo para o conservador partido PFL, o principal parceiro de coalizão do governo de Cardoso. Gustavo Krause, um político do PFL do Nordeste, tornou-se ministro. Durante a primeira administração de Cardoso, a Secretaria de Recursos Hídricos (SRH) tinha mais de 90\% do orçamento do ministério, eclipsando o PPG-7, coordenado pela Secretaria de Coordenação da Amazônia. Em 1999, após a reeleição de Cardoso, o MMA foi reestruturado e o portfólio de irrigação foi retirado do ministério. O PFL ainda chefiava o ministério, mas, dessa vez, com menos poder de barganha por conta de sua perda orçamentária.

O MMA foi entregue a José Sarney Filho, que ainda estava para se estabelecer como um nome forte na política nacional. Sarney Filho nomeou Mary Allegretti para o cargo de secretária de coordenação da Amazônia, que se tornou a secretaria mais importante do ministério naquela gestão. Allegretti tinha um longo histórico de ativismo que começou nos anos 1980 como uma das auxiliares mais próximas de Chico Mendes. Ela era também fundadora de uma ONG, na qual trabalhou nos anos 1980 e 1990 em defesa de políticas socioambientais, com um foco especial em reservas extrativistas. Tinha laços fortes com o movimento dos seringueiros e abriu as portas para esses ativistas durante sua administração. Ela era próxima a Marina Silva, que, na época, era senadora e colaborava regularmente com Allegretti.

\section{As três administrações petistas do MMA}

\section{Gestão Marina Silva}

A indicação do nome de Marina Silva como ministra do Meio Ambiente feita pelo novo presidente da República, Luiz Inácio Lula da Silva, ocorreu quase em concomitância com a de Antônio Palocci para o Ministério da Fazenda. Foram as primeiras indicações do novo presidente e esse ato guardou um simbolismo que surpreendeu a todos, inclusive representantes de ONGs ambientalistas que haviam feito campanha para a nomeação da ativista. A área ambiental foi historicamente marginalizada pelos governos anteriores e aquele ato de Lula sinalizava uma atenção maior a essa pauta, enchendo os ambientalistas de esperança.

A nomeação de Marina era politicamente viável tanto por ela exercer um papel de liderança no Partido dos Trabalhadores como por ser uma ativista ambiental. Ela saltou da posição de agente política relativamente sem experiência em 1994, quando foi eleita senadora da República pelo estado do Acre, para a posição de liderança do partido no Senado no início dos anos 2000. Esse papel fez dela uma escolha fácil, pois 
tinha legitimidade nacional e internacional no movimento ambientalista, mas também no interior do partido.

Durante as diferentes campanhas em que Lula lançou sua candidatura presidencial ou que outros políticos do PT tentaram candidaturas em prefeituras e governos estaduais, e mesmo a cargos do Poder Legislativo, grupos diferentes do movimento ambientalista o apoiaram. Alguns apoiavam candidatos de outros partidos, geralmente de esquerda, mas os ambientalistas contribuíram nas campanhas petistas, especialmente na de 2002, em que Lula foi eleito. Participavam de diferentes reuniões para a montagem de seu plano de governo para a área ambiental e convidavam o candidato para reuniões com apresentações e reflexões sobre o cenário ambiental brasileiro (entrevistas). Eles foram ativos politicamente, aproximando-se do partido em diferentes situações.

A administração de Marina Silva à frente do MMA foi caracterizada pela tensão entre lealdade ao movimento e lealdade ao partido e ficou marcada como a que mais se aproximou da sociedade, tanto por trazer seus representantes para dentro da estrutura ministerial, ao assumir cargos públicos, como também viabilizando sua participação de maneira mais difusa, com consultorias e projetos específicos. Também foram criados e fortalecidos diferentes conselhos de políticas públicas (entrevistas). Ela foi a ministra que primeiro realizou conferência nacional para que a sociedade pudesse participar da elaboração das políticas ambientais do novo governo e para diversificar o diálogo com a sociedade, pois, inicialmente, corria-se o risco de ficar concentrado apenas entre as ONGs ambientalistas que faziam parte do seu ministério (Losekann, 2009). O funcionamento do Conselho Nacional de Meio Ambiente, nesse período, foi intenso e constante, integrando diferentes setores para trabalhar os diversos interesses envolvidos em questões ambientais ${ }^{5}$.

O grupo de ativistas socioambientais se destacou politicamente na primeira gestão petista e no começo da segunda, período em que Marina Silva permaneceu no ministério (de 2003 a 2008). O MMA, nesse período, conseguiu implementar uma política importante de combate ao desmatamento na Amazônia, o Plano de Prevenção e Controle ao Desmatamento na Amazônia, que teve apoio forte da Casa Civil e da Presidência da República ${ }^{6}$. Sua equipe também foi responsável por fortalecer o setor florestal com a criação de 270 unidades de conservação, além da ampliação de mais 20 unidades federais. Registrou-se o equivalente a $695.363 \mathrm{~km}^{2}$ de novas áreas protegidas no Brasil ${ }^{7}$. No campo institucional, a equipe criou o Instituto Chico Mendes de Biodiversidade e Florestas, o Serviço Florestal Brasileiro e elaborou e aprovou a Lei $11.284 / 2006$, de gestão de florestas. Essa gestão também se destacou pelas reformas e

\footnotetext{
${ }^{5}$ Entrevista realizada com especialista em clima e biodiversidade e florestas, abril de 2014.

${ }^{6}$ Entrevista realizada com especialista em biodiversidade e florestas, março de 2014.

7 Fonte: <http://www.oeco.org.br/reportagens/25222-na-contramao-de-dilma-as-areas-protegidas>. Acesso em: 15 mar. 2013.
} 
mudanças institucionais empreendidas ao longo dos cinco anos em que comandou o MMA.

No início do segundo mandato de Lula, em 2007, foram empreendidas reestruturações no $M M A^{8}$, a fim de fortalecê-lo institucionalmente, e ações direcionadas à agenda climática, pois, com o desenvolvimento da pauta de biodiversidade e florestas, a de clima havia ficado para uma outra etapa. A equipe ministerial coordenada por Marina foi também reconhecida por aumentar a importância da agenda ambiental no governo federal, estendendo os compromissos com essa matéria para outros ministérios, numa proposta de transversalidade (entrevistas). Todavia, a tarefa de Marina Silva de elevar a agenda ambiental a outro patamar na esfera pública não foi fácil. Para alguns, sua gestão sofreu grandes derrotas, como a crise dos transgênicos, em 2003, em que a ministra quase entregou o cargo após o governo aprovar legislação de comercialização de produtos agrícolas geneticamente modificados no Brasil (Lisboa, 2011). Mas, para outros, os ganhos superaram os períodos de crises e derrotas.

A tarefa de Marina se tornou ainda mais árdua após a segunda gestão do presidente Lula. Segundo alguns ambientalistas entrevistados, a sensação já presente no primeiro governo - de que não haveria prioridade para as questões ambientais - se intensificou logo no começo da segunda gestão, com o aumento do foco governamental na construção de grandes obras de infraestrutura e no considerável apoio ao setor do agronegócio. Em maio de 2008, após Lula haver anunciado, em reunião com governadores da Amazônia, a revisão do Decreto 6.321/2007 - que fortalecia os mecanismos de prevenção e controle do desmatamento na Amazônia -, de forma a abrandar suas determinações, e a transferência do Plano Amazônia Sustentável, coordenado por Marina Silva, para as mãos de Mangabeira Unger, da Secretaria de Assuntos Estratégicos da Presidência da República, Marina anunciou sua saída do ministério com a famosa alegação de que perdia a cabeça, mas não perdia o juízo.

A partir daquele momento, entrevistados declararam que Marina e sua equipe calcularam que a agenda ambiental vivia um retrocesso em relação à política de desenvolvimento econômico cunhada na expansão do agronegócio e na implementação de obras de infraestrutura de grande porte, como a Usina Hidrelétrica de Santo Antônio e Jirau e a transposição do Rio São Francisco. Um grupo de ambientalistas que ocupava cargos no MMA deixou o ministério juntamente com Marina. Foi esse mesmo grupo que trabalhou na candidatura de Marina Silva à presidência da República em 2010 e a apoiou na criação do partido Rede Sustentabilidade, em 2013.

\footnotetext{
8 Ainda na primeira gestão, Marina havia implementado a carreira de analista ambiental e realizado alguns concursos a fim de fortalecer institucionalmente o ministério, que praticamente não tinha servidor de carreira.
} 
Gestão Carlos Minc

O Ministério do Meio Ambiente foi assumido por Carlos Minc, de maio de 2008 a março de 2010. Minc era militante aguerrido do estado do Rio de Janeiro, fundador do PV, em 1980, mas eleito a deputado estadual, várias vezes, pelo PT. Na ocasião de sua escolha como ministro, Minc estava licenciado de suas funções de parlamentar para chefiar a Secretaria Estadual de Meio Ambiente do Rio de Janeiro.

Como ministro, Minc inicialmente declarou que continuaria a focar nas políticas de combate ao desmatamento e de promoção ao desenvolvimento sustentável. Entretanto, ele teve que lidar com o mesmo obstáculo que sua antecessora: a rápida expansão da agenda de infraestrutura na segunda administração de Lula. A escolha seria deixar a administração ou abnegar de uma postura ambientalista mais radical. Minc escolheu a segunda opção em várias ocasiões. O ato mais simbólico e politicamente importante em relação a isso foi quando o Instituto Brasileiro de Meio Ambiente e Recursos Naturais (Ibama) aprovou a licença ambiental prévia para a continuidade da controversa obra da hidrelétrica de Belo Monte. Apesar disso, durante seu período no MMA, Minc teve sorte ao reportar rápidas quedas na taxa de desmatamento. Ele também se engajou no debate sobre mudanças climáticas, com algum sucesso (Oliveira, 2012).

As ONGs que apoiaram Marina Silva, entretanto, protestavam crescentemente contra a administração de Minc. Em 2010, logo após deixar o ministério para disputar o cargo de deputado estadual pelo Rio de Janeiro, um grupo de organizações da sociedade civil publicou um manifesto de repúdio contra o que eles chamaram o desmantelamento da política ambiental brasileira ${ }^{9}$. Esse documento listou ações do governo do PT que enfraqueceram as regulamentações da política ambiental, tais como o decreto que afrouxou as regras do código florestal; a remoção da legislação de proteção às cavernas, que era obstáculo para projetos de mineração e de eletricidade; e a medida provisória desobrigando a exigência de licença ambiental para expansão e revitalização de estradas ${ }^{10}$. Em outro documento, acusaram os diretores do Ibama de ignorar relatórios técnicos de analistas ambientais que recomendavam rejeitar certas licenças ${ }^{11}$. Para os ambientalistas, esses fatos demonstraram a fragilidade do Ministério do Meio Ambiente em face do projeto do Partido dos Trabalhadores de desenvolvimento econômico e de implementação de obras de grande porte de infraestrutura na Amazônia.

\footnotetext{
${ }^{9}$ Fonte: <http://site-antigo.socioambiental.org/nsa/detalhe?id=2895>. Acesso em: 15 mar. 2013.

10 Fonte: <http://www.planalto.gov.br/ccivil_03/_ato2007-2010/2008/Mpv/452.htm>. Acesso em: 15 mar. 2013.

${ }^{11}$ Fonte: <http://site-antigo.socioambiental.org/nsa/detalhe?id=2895>. Acesso em: 15 mar. 2013.
} 


\section{Gestão Izabella Teixeira}

Em 2011, a presidente recém-eleita, Dilma Rousseff, nomeou Izabella Teixeira para ministra do Meio Ambiente de sua administração. Teixeira havia sido secretária executiva de Minc e ministra interina do MMA no final da segunda gestão de Lula. Ela é bióloga, com doutorado na área de eficiência energética. É servidora do Ibama desde a década de 1980 e assumiu cargos importantes no MMA durante a década de 1990. Ela é a primeira ministra do Meio Ambiente sem atuação partidária ou conexões com a sociedade civil, suas credenciais vieram do conhecimento técnico e de sua reputação de boa administradora.

$\mathrm{Na}$ gestão de Rousseff, grupos econômicos que lutavam contra as regulações ambientais ganharam influência, principalmente no parlamento. Uma grande coalizão de grupos de interesse voltados para o agronegócio trabalhou durante os anos 2011 e 2012 para mudar o código florestal e, apesar da posição crítica do Executivo contra o projeto de lei em negociação e do fato de a presidente Rousseff ter feito vários vetos à nova versão, o novo código florestal foi aprovado. Ele foi considerado pelo grupo de ambientalistas que apoia Marina Silva como o maior retrocesso na política ambiental brasileira. O governo federal também continuou com as pressões para dar andamento a grandes e contenciosas obras de infraestrutura, como Belo Monte, que começou a ser construída após anos de contestação. Novas políticas ambientais assumiram destaque no ministério, como a Bolsa Verde e o Cadastro Rural, enquanto as políticas mais importantes do período anterior perderam importância.

Apesar de alguns ativistas de ONGs ainda trabalharem no MMA, entrevistados notaram que o ministério, na gestão de Teixeira, mudou seu comportamento com as ONGs. O financiamento de projetos foi praticamente cortado e as organizações sociais tiveram pouco espaço para participar das tomadas de decisões políticas, algo de que eles sempre desfrutaram, até mesmo antes da primeira gestão petista. Teixeira foi acusada por lideranças ambientalistas de tentar enfraquecer o papel do Conama e, com isso, dificultar a participação da sociedade civil na regulamentação da política ambiental (entrevistas). O Conama é uma arena tradicional para a mobilização da sociedade civil e é um dos conselhos nacionais que exerce maior influência sobre as políticas públicas (Ipea, 2011).

A mudança no relacionamento com as ONGs contrastava não somente com o período em que Marina havia sido ministra, mas também com o período anterior. Pesquisa de Abers et al. (2000) encontrou formas de participação da sociedade em todos os projetos e subprojetos do PPG-7, o mais importante do MMA durante anos ${ }^{12}$. A nomeação de Teixeira como ministra foi, para vários entrevistados, claramente

\footnotetext{
12 Para maior compreensão sobre a abertura do Ministério do Meio Ambiente à participação da sociedade civil, ver Hochstetler e Keck (2007).
} 
associada ao crescente poder de uma perspectiva específica de ação governamental que privilegiava uma política de desenvolvimento focada em grandes obras de infraestrutura e uma política social de transferência de renda para os mais pobres. Nesse contexto, por exemplo, uma das novas políticas prioritárias do ministério é a Bolsa Verde, um programa que pertence ao Brasil Sem Miséria, o carro-chefe do governo na área social.

Um entrevistado notou que essa e outra política prioritária, o Cadastro Rural, são valorizadas pela atual administração porque produzem resultados mensuráveis, contribuindo para a imagem gerencial que Teixeira busca construir no seu mandato. Enquanto os ministros do Meio Ambiente desde Sarney Filho frequentemente criticavam os programas prioritários da cúpula do governo e defendiam políticas que combatiam os efeitos negativos ambientais de políticas federais de outros setores, Teixeira parece estar bem alinhada com o projeto econômico e social da presidência (entrevistas). Nas palavras de um entrevistado: "Ela presta contas apenas a uma pessoa: a presidente da República". Enquanto outros ministros tinham de justificar suas ações a grupos da sociedade civil ou ao PT, o entrevistado sugere que Teixeira tem obrigações apenas com sua chefe.

Marina Silva após 2008

Após Marina ter deixado o ministério, um grupo de ambientalistas começou a repensar sua estratégia política. O sentimento geral era de que, com a saída de Marina, muitas das conquistas do movimento estavam em risco. Algo importante precisava ser feito para injetar novamente energia no ambientalismo. A ideia de uma campanha de larga escala a favor do desenvolvimento sustentável emergiu numa conferência publicizada e organizada por ONGs após Marina ter saído do ministério ${ }^{13}$.

Durante essa campanha, um número de atores sociais - especialmente jovens que difundiam os ideais de representação política renovada e mais participativa tornou pública a esperança de Marina ser candidata à presidência da República nas eleições de 2010. Para a candidatura ser possível, Marina e muitos dos seus apoiadores se filiaram ao Partido Verde. Essa legenda, de mais de 20 anos de idade, nunca foi de fato uma competidora de destaque na política nacional, mas algo parecia mudar com a candidatura de Marina Silva à presidência da República. O seu grupo de apoio não imaginou que ela ganharia as eleições, mas apostou na estratégia de que uma campanha eleitoral seria boa para trazer questões ambientais para o front da agenda pública. O sucesso eleitoral da campanha surpreendeu a todos. Além do apoio de várias grandes figuras políticas, uma massa de jovens progressistas que buscavam alternativas ao Partido dos Trabalhadores apoiou Marina Silva. A candidata também

13 Fontes: <http://imazon.org.br/imprensa/nota-publica-contra-o-desmonte-da-politica-ambientalbrasileira/ > e <http://site-antigo.socioambiental.org/nsa/detalhe?id=2905>. Acesso em: 19 fev. 2015. 
recebeu apoio de evangélicos protestantes por conta de seu comprometimento religioso. Ao final do primeiro turno do processo eleitoral, a candidata conquistou um vantajoso terceiro lugar na disputa presidencial.

$\mathrm{Na}$ sequência das eleições de 2010, o grupo em torno de Marina começou a sentir que tinha pouco espaço no Partido Verde para a atualização de ideais e de prática política que os seus novos membros procuravam trazer para a legenda. Com isso, eles saíram do PV, junto com Marina, e formaram o Movimento por uma Nova Política. Em seus princípios, o movimento afirmava ser uma experiência de um novo modo de fazer política: horizontal, participativo, democrático, em rede. Em janeiro de 2013, em encontro com apoiadores, Marina defendeu que o movimento já estava pronto para virar um novo partido político com o objetivo de "criar uma nova cultura política" no país ${ }^{14}$.

Em 16 de fevereiro de 2013, foi lançada a Rede Sustentabilidade. A Rede se defrontava com o grande desafio de conseguir recolher cerca de $500 \mathrm{mil}$ assinaturas até setembro do mesmo ano, para se oficializar como partido apto a participar das eleições de 2014. Seus militantes registraram em torno de 800 mil assinaturas válidas, mas boa parte não foi reconhecida pelos cartórios eleitorais, e o Tribunal Superior Eleitoral Ihe negou o registro partidário. Na sequência do parecer negativo, Marina e alguns do seu grupo de apoio (um número bem menor do que aquele que se filiou ao PV) se filiaram ao Partido Socialista Brasileiro (PSB) para apoiar a candidatura de Eduardo Campos, candidato a presidente da República pelo PSB, que confirmou, em 14 de abril de 2014, o nome de Marina Silva como sua vice. Os ambientalistas, que há dez anos haviam participado do governo petista, na segunda metade do governo Dilma, estabeleceramse não somente como críticos, mas como membros ativos da oposição eleitoral.

\section{As trajetórias profissionais e políticas dos nomeados}

Atualmente, no serviço público, há o registro de mais de 2 milhões de servidores federais que assumiram seus cargos por meio de concursos públicos ${ }^{15}$. Quando Marina Silva chefiou o MMA, em 2003, o órgão tinha poucos servidores públicos. A maioria da equipe ministerial era composta por consultores contratados por meio de organismos internacionais, como o Programa das Nações Unidas para o Desenvolvimento (PNUD). Esses consultores eram relativamente bem pagos comparados a muitos servidores, mas não tinham estabilidade nem direitos trabalhistas.

\footnotetext{
14 Fonte: <http://www.estadao.com.br/noticias/nacional, movimento-esta-preparado-para-virar-partidodiz-marina, 987534,0.htm >. Acesso em: 24 abr. 2014

${ }^{15}$ Boletim Estatístico de Pessoal (2013).
} 
Lula, ao assumir o governo, por recomendação do Ministério Público da União, comprometeu-se a acabar com esse tipo de contrato considerado precário e realizou vários concursos públicos para fortalecer a burocracia estatal. Marina Silva aproveitou essa oportunidade para consolidar a carreira de especialista em meio ambiente, criando, ao longo dos cinco anos de sua gestão, 1.474 novas vagas no Ministério do Meio Ambiente e em suas autarquias, as quais foram preenchidas por meio de concursos públicos. De 2003 a 2013 foram criadas, ao todo, 2.258 novas vagas para a carreira de analista ambiental ${ }^{16}$.

Nossos dados, contudo, focam num conjunto diferente de cargos públicos, os cargos de confiança ou os formalmente intitulados cargos de Direção e Assessoramento Superior (DAS). Existem no governo federal brasileiro em torno de 22 mil cargos de confiança, classificados em seis níveis. O nível 6 corresponde ao segundo escalão de empregados, são os secretários que se encontram logo abaixo dos ministros. O nível 5 corresponde ao cargo de diretor de departamento das secretarias, e os cargos de nível 4 são preenchidos por coordenadores gerais e gerentes de projetos e programas. De acordo com Praça, Freitas e Hoepers (2012, p. 145), o governo federal tem 5.467 nomeados no nível 4, 5 e 6, e mais de 17.114 trabalhadores nos níveis de 1 a 3, que são cargos mais administrativos.

Desde 2005, foi estabelecido pelo Decreto no 5.497, publicado pelo governo federal, que $75 \%$ dos nomeados a cargos DAS de 1 a 3 e $50 \%$ dos nomeados a DAS 4 devem ser servidores públicos, uma decisão que reduziu drasticamente a possibilidade de patronagem para esses níveis mais baixos de nomeação. Os níveis 5 e 6 dos cargos DAS são de livre nomeação, não precisam ser preenchidos por servidores públicos, apesar de muitos dos que assumem esses cargos serem servidores de carreira do Estado (Praça, Freitas e Hoepers, 2012, p. 145) ${ }^{17}$. A base de dados com que trabalhamos inclui 147 pessoas, 110 que foram nomeadas apenas para cargos DAS 5, 30 pessoas que foram nomeadas apenas para DAS 6 e sete pessoas que foram nomeadas para cada um dos dois cargos, de 2003 a 2013, nos 11 anos de gestão petista no governo federal. Devemos notar que não se trata de uma amostra probabilística, e, sim, de um censo, já que coletamos dados sobre todos os indivíduos com cargos DAS 5 ou 6 nomeados para o MMA ao longo desse período.

A Tabela 1 reúne os principais dados coletados para a população pesquisada como um todo e para os nomeados de cada gestão ministerial desde que o PT assumiu

\footnotetext{
16 De 1995 a 2002, nenhum concurso público foi realizado para ingresso de novos servidores públicos no Ministério do Meio Ambiente nem em suas autarquias. A carreira de especialista em meio ambiente foi criada em 2002 e os concursos para analista ambiental, cargo de nível superior dessa carreira, começaram a acontecer a partir da gestão petista. Cf. Boletim Estatístico de Pessoal (2011, 2012 e 2013).

17 De acordo com Boletim Estatístico de Pessoal (2013), disponibilizado pelo governo federal, em dezembro de 2013 havia 1.302 cargos de DAS 5 e 6 sendo ocupados. Entretanto, o Boletim não especifica quantos desses ocupantes eram servidores públicos.
} 
a presidência. Ao analisar os dados de forma global, na última coluna da Tabela 1, salta aos olhos a baixa presença de pessoas filiadas ao PT em um ministério que foi comandado por esse partido durante os seus 11 anos de gestão: $20 \%$ ( 29 pessoas) $^{18}$. 0 número de pessoas nomeadas que tiveram experiência de trabalho em ONG ambientalista antes de assumir cargos no MMA era um pouco maior do que o número de petistas, 22\% (32 pessoas). Também detectamos 12 pessoas ( $8 \%$ ) com relações próximas de militância ou assessoria a movimentos sociais. Como alguns dos que trabalharam em ONG também tinham experiências como militantes de movimentos sociais (sem vínculo empregatício), chegamos a um total de 40 pessoas ou $27 \%$ do total com experiências de trabalho ou de militância em movimentos sociais ou organizações da sociedade civil.

Há pouca sobreposição entre esse grupo e os petistas: somente 11 das 40 pessoas com experiência em ONGs ou movimentos sociais eram filiadas ao PT na época de suas nomeações. Se entendermos contratações de petistas e pessoas conectadas a movimentos sociais como duas formas de privilegiar aliados políticos, surpreende o fato de que, no MMA, parece ter havido maior espaço para movimentos sociais (entendidos de forma ampla) do que para pessoas do mesmo partido dos ministros e dos presidentes.

Nenhuma das categorias mais "políticas" chega ao tamanho do grupo de pessoas recrutadas de dentro da máquina pública federal. Quase a metade dos nomeados $(46 \%)$ eram servidores públicos no momento da primeira nomeação, sem incluir 11 pessoas que eram professores concursados em universidades federais. Outras 24\% tinham experiência de trabalho no governo federal, mas não eram servidores públicos federais. A maioria desse segundo grupo havia trabalhado no governo federal em outros cargos comissionados, provavelmente de níveis mais baixos. Muitos (37\%) tinham experiência de militância ou trabalho em movimentos sociais e $31 \%$ eram petistas.

Os servidores públicos contratados para cargos de alto escalão no MMA apresentam características diferentes daqueles vindos da sociedade civil. São pessoas com pouca experiência de atuação política: apenas $11 \%$ eram filiadas ao PT e $12 \%$ traziam experiência de trabalho ou militância em ONGs ou movimentos sociais. Portanto, o recrutamento dessas pessoas pode ser interpretado como sinal de uma política de nomeação "técnica" e não de patronagem. Outros dados sugerem uma preferência por nomeados bem qualificados em todas as gestões: $26 \%$ de todos os nomeados têm doutorado e $18 \%$ têm mestrado acadêmico (sem incluir cursos de especialização ou pós-graduação lato sensu).

\footnotetext{
18 Essa porcentagem é consistente com os dados de D’Araújo (2009), que realizou pesquisa com 302 atores com DAS 5 ou 6 , no primeiro governo Lula, e 417, no segundo. Aproximadamente $20 \%$ declararam ser filiados ao PT. O número de 29 pessoas filiadas ao PT é baixo se comparado ao total das 147 trajetórias pesquisadas para o Ministério do Meio Ambiente.
} 
Ao longo de mais de dez anos, o MMA nomeou para os cargos politicamente estratégicos apenas oito pessoas que já haviam ocupado cargos eleitorais, como o de deputado federal ou estadual. Em resumo, há vários indicadores de que a tomada de decisão sobre nomeações no ministério privilegiou mais a escolha de pessoas com experiência e qualificação técnica do que a de pessoas com biografias mais politizadas, em partidos políticos, nos movimentos sociais, ou mesmo em cargos eleitorais.

A Tabela 1 também possibilita verificar que esse quadro mudou ao longo do tempo. Praticamente todas as categorias estudadas, com exceção dos servidores públicos e das pessoas com pós-graduação, perderam espaço ao longo do tempo. A diminuição da parcela de nomeados com trajetórias em ONGs e em movimentos sociais (que trabalharam em ONG ou assessoraram organização social) foi expressiva: esse grupo representava 39\% dos nomeados na gestão de Marina Silva e foi reduzido para apenas $24 \%$ na gestão de Izabella Teixeira.

Contudo, as outras categorias estudadas também diminuíram: o número de petistas passou de $22 \%$ dos nomeados durante a gestão Marina para $17 \%$ na gestão Izabella; a parcela que havia trabalhado no governo federal, mas que não era servidor, foi de $28 \%$ para 15\%; a porcentagem com experiência em órgãos municipais e estaduais diminuiu de $34 \%$ para $20 \%$; o montante que já havia trabalhado como professor universitário foi de $27 \%$ para $17 \%$; e o total com experiência de trabalho em consultoria foi de $21 \%$ para $13 \%$. Isto é, a comparação entre as administrações sugere uma mudança de preferência cada vez maior em favor de pessoas com credenciais técnicas e acadêmicas e por pessoas que pertencem aos quadros permanentes do governo federal, em detrimento de pessoas recrutadas em organizações externas ${ }^{19}$ :

\footnotetext{
${ }^{19}$ Os resultados verificados a partir da análise das trajetórias dos ocupantes de cargos DAS 5 e 6 no MMA encontram o que D'Araújo (2009) observou sobre o perfil desses dirigentes no total da administração pública durante a primeira e a segunda gestão do governo Lula: são, na maioria, servidores públicos; possuem alto nível de formação educacional e expressiva ligação com o PT, com sindicatos, movimentos sociais e organizações de gestão local.
} 
Tabela 1

Experiências profissionais e políticas dos nomeados a DAS 5 e 6 no MMA por gestão

\begin{tabular}{|c|c|c|c|c|c|c|c|c|c|}
\hline \multirow{2}{*}{\multicolumn{2}{|c|}{ Experiências }} & \multicolumn{2}{|c|}{$\begin{array}{l}\text { Gestão } \\
\text { Marina } \\
\text { Silva } \\
(2003- \\
2007) \\
\end{array}$} & \multicolumn{2}{|c|}{$\begin{array}{l}\text { Gestão } \\
\text { Carlos } \\
\text { Minc } \\
(2008- \\
2010) \\
\end{array}$} & \multicolumn{2}{|c|}{$\begin{array}{c}\text { Gestão } \\
\text { I zabella } \\
\text { Teixeira } \\
\text { (2011-- } \\
\text { 2013) } \\
\end{array}$} & \multicolumn{2}{|c|}{$\begin{array}{l}\text { Totais } \\
(2003 \text { a } \\
2013)\end{array}$} \\
\hline & & № & $\%$ & № & $\%$ & № & $\%$ & № & $\%$ \\
\hline No partido & Filiado ao PT & 15 & 22 & 15 & 21 & 13 & 17 & 29 & 20 \\
\hline \multirow{3}{*}{$\begin{array}{l}\text { Nos } \\
\text { movimentos } \\
\text { sociais }\end{array}$} & Trabalhou em ONG & 18 & 27 & 16 & 22 & 16 & 21 & 32 & 22 \\
\hline & $\begin{array}{l}\text { Assessorou } \\
\text { organização social }\end{array}$ & 11 & 16 & 7 & 10 & 5 & 7 & 12 & 8 \\
\hline & $\begin{array}{l}\text { Trabalhou em ONG ou } \\
\text { assessorou } \\
\text { organização social }\end{array}$ & 26 & 39 & 20 & 27 & 18 & 24 & 40 & 27 \\
\hline \multirow{4}{*}{ No Estado } & $\begin{array}{l}\text { Era servidor público } \\
\text { federal* }\end{array}$ & 23 & 34 & 33 & 45 & 48 & 64 & 67 & 46 \\
\hline & $\begin{array}{l}\text { Trabalhou em órgão } \\
\text { federal sem ser } \\
\text { servidor público } \\
\text { federal* }\end{array}$ & 19 & 28 & 21 & 29 & 11 & 15 & 35 & 24 \\
\hline & $\begin{array}{l}\text { Trabalhou em órgão } \\
\text { municipal ou estadual }\end{array}$ & 23 & 34 & 20 & 27 & 15 & 20 & 41 & 28 \\
\hline & Teve cargo eleitoral & 4 & 6 & 6 & 8 & 3 & 4 & 8 & 5 \\
\hline \multirow{3}{*}{$\begin{array}{l}\text { Em outros } \\
\text { lugares }\end{array}$} & $\begin{array}{l}\text { Trabalhou como } \\
\text { professor universitário }\end{array}$ & 18 & 27 & 18 & 25 & 13 & 17 & 32 & 22 \\
\hline & $\begin{array}{l}\text { Fez doutorado ou } \\
\text { mestrado acadêmico }\end{array}$ & 30 & 45 & 31 & 42 & 38 & 51 & 65 & 44 \\
\hline & Foi consultor & 14 & 21 & 12 & 16 & 10 & 13 & 27 & 18 \\
\hline \multicolumn{2}{|c|}{ Número total de nomeados } & 67 & 100 & 73 & 100 & 75 & 100 & 147 & 100 \\
\hline
\end{tabular}

Fonte: Pesquisa coordenada pelas autoras a partir de base de dados do Instituto de Pesquisa Econômica Aplicada (Ipea) e consulta ao Diário Oficial da União.

* Não inclui professores universitários.

A pesquisa qualitativa realizada ajuda a interpretar essas variações. Sabemos que, quando Marina Silva assumiu o ministério, ela levou consigo um conjunto de atores que antes trabalhavam em ONGs. Uma ONG específica, o Instituto Socioambiental (ISA), teve um papel de destaque na escolha de um dos seus militantes, João Paulo Capobianco, para o cargo de secretário de Biodiversidade e Florestas. Entrevistados do ISA nos explicaram que Capobianco foi escolhido pelos membros do próprio instituto. Sabia-se que a ministra procuraria a entidade, que concluiu que Capobianco seria o mais bem cotado para assumir um cargo governamental. Além de sua experiência gestora, o grupo entendia que ele tinha capacidade técnica destacada para conduzir uma das principais agendas ambientais que o governo e um grupo de ambientalistas vinham desenvolvendo conjuntamente, a de biodiversidade e florestas. 
Segundo entrevistados, o objetivo não era apenas entrar no governo, mas fazer avançar os projetos específicos que esse grupo de ambientalistas socioambientais priorizava. Ao longo do período em que Marina foi ministra, Capobianco ganhou importância cada vez maior no ministério. A Secretaria de Biodiversidade e Florestas se tornou a mais poderosa do ministério no primeiro governo do PT. No início da segunda gestão, Capobianco se tornou o secretário executivo do ministério.

Vários outros secretários nomeados no início da gestão de Marina eram pessoas oriundas da sociedade civil: Marijane Lisboa, ativista do Greenpeace, foi nomeada secretária de Qualidade Ambiental; Mary Alegretti, com fortes conexões com o movimento dos seringueiros, continuou responsável pela Secretaria de Coordenação de Assuntos da Amazônia, tarefa que executava desde o governo anterior, de 1999 a 2002. Essas duas pessoas ficaram pouco tempo no governo petista. Mary Alegretti foi substituída por Muriel Saragoussi, que antes da administração de Marina havia trabalhado na ONG Fundação Vitória Amazônica. Marijane Lisboa foi substituída por Victor Zular Aveibil, funcionário de um instituto privado de pesquisa que também havia sido secretário de Meio Ambiente em município do estado do Rio de Janeiro.

Outros secretários nomeados por Marina eram militantes do PT na área ambiental. Gilney Vianna, deputado federal que militava em prol de questões ambientais, foi nomeado chefe da Secretaria de Desenvolvimento Sustentável (SDS). J oão Bosco Senra, um engenheiro que havia chefiado o órgão de gestão de água do estado de Minas Gerais, tornou-se secretário de Recursos Hídricos no MMA. Claudio Langone, que havia administrado o órgão ambiental do governo do Rio Grande do Sul, foi o primeiro secretário executivo de Marina. Em suma, todos os secretários nomeados no início da administração de Marina Silva ou tinham trajetória profissional de ativismo em ONGs ou assumiram cargos políticos anteriormente associados ao PT.

Ao assumir o ministério em 2008, Minc acabou substituindo a maioria daqueles que foram nomeados por Marina Silva aos cargos DAS 6 e 5. Apenas dois secretários que participaram da segunda gestão da ex-ministra permaneceram: a secretária de Biodiversidade e Florestas, Maria Cecília Wey de Brito, e o secretário de Desenvolvimento Sustentável, Egon Krakhecke. Brito assumiu o lugar de Capobianco na SBF quando ele se tornou secretário executivo do ministério em 2007. Ela trabalhou anteriormente no governo do estado de São Paulo. Krakhecke substituiu Gilney Viana, em 2007, e, tal como seu predecessor, era vinculado ao Partido dos Trabalhadores. Ele foi vice-governador pelo partido no estado do Mato Grosso do Sul.

Para a Secretaria de Mudanças Climáticas e Qualidade Ambiental, criada em 2007, Minc nomeou Suzana Kahn Ribeiro, engenheira mecânica e professora universitária. Vicente Guillo, servidor da CPFL, empresa de energia no estado de São Paulo, foi nomeado para chefiar a Secretaria de Recursos Hídricos e Ambiente Urbano. Ele foi secretário de Desenvolvimento Urbano em Campinas, São Paulo. Minc nomeou 
Izabella Teixeira, servidora do Ibama, como sua secretária executiva. A única pessoa nomeada para assumir um cargo DAS 6 e que vinha de experiência profissional em ONG foi Samyra Crespo, que coordenou a Secretaria de Articulação Institucional e Cidadania. Ela era vinculada ao Instituto de Estudos Religiosos (Iser), situado no Rio de Janeiro, mas Crespo também era servidora pública licenciada do Ministério da Ciência e Tecnologia. Em uma visão geral, a Tabela 1 registra um crescimento da parcela de servidores públicos e uma ligeira diminuição da porcentagem de pessoas com experiência em órgãos municipais e estaduais, bem como em ONGs e movimentos. Outras categorias se mantiveram estáveis na administração de Minc: a parcela de petistas, de professores universitários, de pessoas com pós-graduação é quase idêntica à da gestão anterior, mesmo quando, em muitos casos, as pessoas eram outras.

A administração de Teixeira mostra mudanças ainda mais fortes do que aquelas já iniciadas por Minc. Tal como na gestão de seu antecessor, a única secretária com experiência em ONG era Samyra Crespo, que permaneceu no mesmo cargo. Para a Secretaria de Recursos Hídricos e Ambiente Urbano, Teixeira nomeou Nabil Bonduki, provavelmente o único secretário com conexões mais próximas com movimentos sociais, especialmente o movimento urbano e ambiental do estado de São Paulo. Ele é professor universitário e também guarda fortes laços com o PT. Bráulio Dias, professor universitário, com perfil mais técnico, assumiu a SBF. Para a SDS, foi nomeado Roberto Vizentin, que assessorou Gilney Viana em suas atividades políticas no Mato Grosso e também quando foi deputado federal. Tanto Vizentin quanto Dias foram nomeados a cargos diferentes no MMA desde 2003. Eduardo Assad, outro professor universitário e pesquisador da Empresa Brasileira de Pesquisa Agropecuária (Embrapa), assumiu a Secretaria de Mudanças Climáticas.

Teixeira nomeou para sua equipe ministerial um número ainda maior de servidores públicos: $64 \%$ de todos os nomeados na sua gestão. Embora o número de pessoas que haviam trabalhado como professor universitário tenha diminuído o número de pessoas com pós-graduação acadêmica aumentou. Dos 48 servidores públicos nomeados para DAS 5 ou 6 na gestão de Izabella Teixeira, 30\% tinham doutorado e $21 \%$, mestrado acadêmico.

$\mathrm{Na}$ mesma gestão, a parcela de petistas baixou para apenas $17 \%$ dos nomeados. A parcela de pessoas ligadas a ONGs e movimentos sociais baixou para 21\%. A mudança se exacerba durante a gestão de Izabella Teixeira: se em 2011 a ministra nomeou 14 pessoas com experiência de trabalho ou militância em ONGs ou movimentos sociais, em 2013, somente 8 delas sobravam em cargos de alto escalão. Para alguns entrevistados, a candidatura de Marina Silva influenciava as nomeações e exonerações. Alguns deixaram o ministério voluntariamente para trabalhar para a candidatura dela. Outros não eram diretamente envolvidos na criação do novo partido 
que Marina liderava, porém reclamavam que o clima era cada vez mais hostil para quem era associado aos movimentos ambientalistas.

Como a mudança nas relações entre ambientalistas e o governo do PT influenciou as nomeações políticas apresentadas nesta seção e em que medida podemos atribuir as mudanças no padrão de nomeações aos crescentes conflitos políticos entre o grupo de ONGs que apoiavam Marina e o governo Dilma? Pela análise quantitativa das biografias das pessoas nomeadas para cargos de confiança de alto escalão do Ministério do Meio Ambiente, torna-se difícil atribuir as variações das nomeações apenas a conflitos políticos entre movimentos sociais e o governo.

\section{A transformação da relação entre Estado e sociedade civil na era petista}

A análise dos dados quantitativos sobre o governo sugere que atribuir a mudança no perfil das nomeações à polarização política entre os ambientalistas que apoiaram Marina Silva e a cúpula do governo do PT é uma explicação apenas parcialmente correta. Observa-se que o acirramento do conflito entre Marina Silva e o governo resultou na saída de diversos atores do MMA que tinham laços com movimentos sociais e com a sociedade civil. No entanto, a mudança no perfil das nomeações vai além do papel do grupo de ONGs que participaram do ministério na época da Marina. Ao longo do período analisado, todas as categorias de atores, exceto servidores públicos federais, perderam peso: pessoas que vieram de governos estaduais e municipais, professores universitários e consultores também perderam espaço no ministério. Até a parcela de nomeados com filiação ao PT diminuiu. Como podemos entender essa mudança no perfil dos nomeados no Ministério do Meio Ambiente?

Primeiramente é importante lembrar que em nenhum momento ao longo do período analisado predominaram nomeações que poderíamos identificar com "patronagem" no sentido de terem como função única a garantia de apoios políticos: nem os filiados ao partido dos ministros (e dos presidentes) foram privilegiados nas contratações. Petistas representaram pouco mais do que um quinto dos nomeados nas gestões de Marina Silva e Carlos Minc e um pouco menos na gestão de Izabella Teixeira.

Será que a patronagem no MMA ocorreu através da nomeação de pessoas ligadas a movimentos sociais? Nesse sentido, um possível argumento para compreender as nomeações feitas por Marina Silva seria o fato de ela ter levado para dentro do ministério pessoas de confiança política tanto do partido quanto das ONGs, o que Scherlis (2009) chamaria de patronagem por relações pessoais. A nossa interpretação dos dados, no entanto, sugere que a maior presença de pessoas ligadas aos movimentos durante a gestão de Marina se devia em grande parte à necessidade da ministra de recrutar recursos humanos capacitados. Vários entrevistados sugeriram que a ida de ativistas para cargos governamentais não se devia apenas a relações pessoais 
ou políticas, ou à tentativa da ministra de se cercar de pessoas "de confiança", embora isso também possa ter acontecido. Uma outra razão que pode justificar o fato de ter sido chamado um grande número de profissionais de ONGs para assumir cargos de confiança no MMA era para possibilitar ao ministério o acesso de uma expertise técnica, que naquele momento era mais forte na sociedade civil do que no próprio Estado.

O MMA, conforme dito anteriormente, tinha pouquíssimos funcionários concursados no início do governo Lula. O ministério era frágil em termos técnicos e dependia de contratos e convênios com entidades externas, especialmente com organizações não governamentais, para realizar atividades diversas. Mesmo antes de 2003, o MMA mantinha as portas abertas para ONGs ambientalistas em grande parte para poder aproveitar a capacidade técnica que algumas daquelas organizações haviam desenvolvido ao longo da década anterior.

Durante a década de 2000, esses trabalhadores foram paulatinamente substituídos por concursados. Foram criadas 2.258 novas vagas, fortalecendo, assim, a carreira de analista ambiental e, consequentemente, o MMA. Dessa forma, podemos dizer que se criou um pool de funcionários qualificados e permanentes na área ambiental que antes não existia. Isso não resultou automaticamente no incremento de nomeações de diretores e secretários oriundos daquele grupo. Diferente dos níveis mais baixos de nomeação, os cargos DAS 5 e DAS 6 não precisam ser obrigatoriamente assumidos por servidores públicos. Podemos, assim, entender que a crescente presença de servidores públicos entre os nomeados a cargos estratégicos reflete uma decisão política. Uma decisão que se tornou mais fácil com o crescimento do número de servidores públicos qualificados em matéria ambiental.

Nossa interpretação desse processo, baseada nas informações colhidas nas entrevistas, é que a intensificação das contratações de servidores públicos reflete não somente o fato de um esfriamento das relações entre o governo e o movimento ambientalista, mas também uma diminuição da dependência do governo federal em relação às ONGs para alcançar expertise técnica. Se antes as ONGs serviam como fonte de capacidade, hoje o governo encontra essa capacidade no interior do seu corpo burocrático.

O Ministério do Meio Ambiente se tornou mais insulado, não somente perante a sociedade civil, mas também em relação a todos os atores externos que antes participavam de cargos de alto escalão. Esse insulamento certamente reflete as preferências políticas da ministra Izabella Teixeira - conhecida como "tecnocrata" - e da própria presidente da República. Mas isso somente foi possível porque o governo petista investiu na criação de um corpo burocrático concursado.

Esse resultado nos parece importante não somente para compreender a política ambiental, mas como evidência de que pode ter ocorrido mudanças profundas na relação entre o governo petista e a sociedade civil nos últimos 11 anos, pelo menos na 
medida em que o Ministério do Meio Ambiente seja representativo do governo como um todo (e estamos conscientes de que é um caso com algumas singularidades). Se analistas como Ribeiro (2008) argumentaram que, antes de assumir o poder federal, o PT passou por um processo de aproximação do Estado e de distanciamento da sociedade civil, os anos como partido no governo parecem ter intensificado esse processo. Se, por um lado, esse processo contraria acusações de que o governo petista é capturado por interesses econômicos e sociais, por outro, sugere que os movimentos sociais que lutam por justiça social e ambiental hoje têm menos influência no governo federal.

Em resumo, os dados analisados neste artigo chamam a atenção para uma possível transformação do "modo petista de governar" que se sustenta em mudanças no próprio Estado. O governo petista pôde se distanciar dos movimentos sociais e de outros atores da sociedade justamente porque ao longo dos últimos anos se construiu uma base de apoio técnico no interior do próprio governo federal. Se antes precisava dos movimentos sociais não somente para apoio político, mas também como fontes de ideias e capacidades, hoje o PT construiu outra fonte de apoio técnico. Esse processo tende a se acentuar, pelo menos enquanto o partido mantiver o controle da presidência da República.

Rebecca Neaera Abers - Instituto de Ciência Política, Universidade de Brasília. E-mail: <rebecca.abers@gmail.com>.

Marília Silva de Oliveira - Doutoranda no Instituto de Ciência Política, Universidade de Brasília. E-mail: <mariliasoliveira@gmail.com>.

\section{Referências bibliográficas}

Abers, R. N.; Serafim, L.; TATAGiBA, L. "Repertórios de interação Estado-sociedade em um Estado heterogêneo: a experiência na era Lula". Dados - Revista de Ciências Sociais, Rio de Janeiro, vol. 57, n² 2, p. 325-357, abr.-jun. 2014.

ABERS, R. N.; Von BüLoW, M. "Movimentos sociais na teoria e na prática: como estudar o ativismo através da fronteira entre Estado e sociedade?". Sociologias, Porto Alegre, vol. 13, n²8, p. 52-84, set.-dez. 2011.

ABERS, R., et al. Civil society participation in the pilot program to conserve the Brazilian rain forest. Manuscrito não publicado, Brasília, 2000.

ALONSO, A.; COSTA, V.; MACIEL, D. "Identidade e estratégia na formação do movimento ambientalista brasileiro". Novos Estudos Cebrap, São Paulo, vol. 4, n 70, p. 151-167, nov. 2007.

AmARAL, O. "Ainda conectado: o PT e seus vínculos com a sociedade". Revista Opinião Pública, Campinas, vol. 17, $\mathrm{n}^{\circ}$ 1, p. 1-44, jun. 2011. 
BERSCH, K.; PRAÇA, S.; TAYLOR, M. "State capacity and bureaucratic autonomy within national states: mapping the archipelago of excellence in Brazil". In: Princeton-Oxford State Building Workshop, Oxford University, p. 1-31, May 2013.

BRANFORD, S. Lidando com governos: o MST e as administrações de Cardoso e Lula. In: CARTER, M. (org.). Combatendo a desigualdade social: o MST e a reforma agrária no Brasil. São Paulo: Unesp, 2009.

BRASIL. Boletim Estatístico de Pessoal e Informações Organizacionais. Ministério do Planejamento, Orçamento e Gestão. Secretaria de Gestão Pública, vol. 18, n²12, Brasília: MP, 2013.

CARDOSO J R., J. C. Burocracia e ocupação no setor público brasileiro. Rio de Janeiro: Ipea, 2011.

CRUZ, R. Carreiras burocráticas e suas transformações: o caso dos gestores governamentais no Brasil. In: Loureiro, M. R. G.; ABRUCIO, F. L.; PACHECO, R. S. P. (orgs.). Burocracia e política no Brasil: desafios para a ordem democrática no século XXI. Rio de Janeiro: FGV Editora, 2010.

Dagnino, E.; Olvera, A. J.; PANFichI, A. Para uma outra leitura da disputa pela construção democrática na América Latina. In: DAgnino, E.; Olvera, A. J.; PANFiCHI, A. (orgs.). A disputa pela construção democrática na América Latina. São Paulo: Paz e Terra, 2006.

D'ARAújo, M. C. A elite dirigente do governo Lula. Rio de Janeiro: CPDOC, 2009

D'ARAújo, M. C. (org.). Governo Lula: contornos sociais e políticos da elite no poder. Rio de Janeiro: CPDOC, 2007.

DE WINTER, L. "Sixty years of party patronage in the Belgian partitocracy: quantitative and qualitative transformations". In: ECPR J oint Sessions of Workshops, Nicosia, 25-30, April 2006.

DowBoR, M. "Arte da institucionalização: estratégias de mobilização dos sanitaristas (19742006)". Tese de Doutorado em Ciência Política. 295p. Faculdade de Filosofia, Letras e Ciências Humanas, FFLCH-USP, São Paulo, 2012.

Drummond, J.; Barros-Platiau, A. F. "Brazilian environmental laws and policies, 1934-2002: a critical overview". Law and Policy, Denver, vol. 28, n 1, p. 83-108, January 2006.

FELTRAN, G. S. Descolamentos - trajetórias individuais, relações entre sociedade civil e Estado no Brasil. In: DAGNINO, E.; OlverA; A. J.; PANFICHI, A. A disputa pela construção democrática na América Latina. São Paulo: Paz e Terra, 2006.

FIGUEIREDo, A. Executivo e burocracia. In: LESSA, R. (org.). Horizontes das ciências sociais no Brasil: ciência política. São Paulo: Anpocs, 2010.

FRANCO, J. L. A. "Proteção à natureza e identidade nacional: 1930-1940". Tese de Doutorado em História. Instituto de Ciências Humanas, IH/UnB, Brasília, 2002.

GEDDES, B. "Building 'state' autonomy in Brazil, 1930-1964". Comparative Politics, New York, vol. 22, n², p. 217-235, January 1990.

GenRo, L.; RobalnA, R. A falência do PT e a atualidade da luta socialista. Porto Alegre: L\&PM, 2006.

HOCHSTETLER, K.; KECK, M. E. Greening Brazil: environmental activism in State and society. Durham/London: Duke University Press, 2007.

I PEA. "Processo político e decisório no âmbito do Conselho Nacional de Meio Ambiente (Conama)". Relatório de Pesquisa. Brasília: Ipea, 2011. 
KATZ, R. S.; MAIR, P. "The evolution of party organizations in Europe: the three faces of party organization". American Review of Politics, Arkansas, vol. 14, n 4, p. 593-617, 1993.

"Changing models of party organization and party democracy: the emergence of the Cartel Party". Party Politics, Ohio, vol. 1, nº 1, p. 5-28, January 1995.

KECK, M. E. The Workers' Party and democratization in Brazil. New Haven: Yale University Press, 1992.

KECK, M. E.; SIKKINK, K. Activists beyond borders. New York: Cornell University Press, 1998.

LAMEIRÃo, C. R. A ordenação dos cargos de direção e assessoramento superiores (DAS) como estratégia para o fortalecimento institucional e decisório do presidente da República. In: CARDOSO JR., J. C.; PIRES, R. R. C. (orgs.). Gestão pública e desenvolvimento. Brasília: I pea, 2011.

LISBOA, M. V. Balanço da política ambiental do governo Lula: grandes e duradouros impactos. In: PAULA, M. (org.). Nunca antes na história desse país...? Um balanço das políticas do governo Lula. Rio de Janeiro: Heinrich Böll Stiftung, 2011.

LOPEZ, F. G.; BugARIN, K.; BugARIN, M. "Partidos, facções e a ocupação de cargos de confiança no Executivo federal (1999-2011)". In: Anais do Encontro Anual da Anpocs, 37. Caxambu, Anpocs, p. 1-27, 2013.

LOSEKANN, C. "A presença das organizações ambientalistas da sociedade civil no governo Lula (2003-2007) e as tensões com os setores econômicos". Tese de Doutorado em Ciência Política. Instituto de Filosofia e Ciências Humanas, IFCH/UFRS, Porto Alegre, 2009.

Loureiro, M. R.; Olivieri, C.; MARTES, A. C. B. Burocratas, partidos e grupos de interesse: o debate sobre política e burocracia no Brasil. In: LOUREIRO, M. R.; ABRúCIO, L. F.; PACHECO, R. S. Burocracia e política no Brasil: desafios para a ordem democrática no século XXI. Rio de Janeiro: FGV, 2010.

MARCONI, N. Uma radiografia do emprego público no Brasil: análise e sugestões de políticas. In: Loureiro, M. R.; ABrúcio, L. F.; PACHECO, R. S. Burocracia e política no Brasil: desafios para a ordem democrática no século XXI. Rio de Janeiro: FGV, 2010.

Meneguello, R. PT: a formação de um partido. Rio de Janeiro: Paz e Terra, 1989.

OliveirA, A. L. N. "Ação coletiva na redução de emissões de carbono por desmatamento e degradação: a atuação de organizações da sociedade civil brasileira entre 2005 e 2010". Dissertação de Mestrado em Ciência Política. Instituto de Ciência Política, UnB, Brasília. 2012.

PraçA, S.; Freitas, A.; Hoepers, B. "Political appointments and coalition management in Brazil, 2007-2010". Journal of Politics in Latin America, Hamburg, vol. 3, n² 2, p. 141-72, 2011.

PraçA, S.; FreitAs, A.; Hoepers, B. "A rotatividade dos servidores de confiança no governo federal brasileiro: 2010-2011". Novos Estudos Cebrap, São Paulo, n 94, p. 91-107, nov. 2012.

Ralle, E.; Pereira, C.; Power, T. "The Executive toolbox: building legislative support in a multiparty presidential regime". Political Research Quarterly, Utah, vol. 64, n² 2, p. 323-34, March 2011

RIBEIRo, P. J. F. "Dos sindicatos ao governo: a organização nacional do PT de 1980 a 2005". Tese de Doutorado em Ciência Política. Centro de Educação e Ciências Humanas, UFSCar, São Carlos, 2008.

RibeiRo, P. J. F. "An amphibian party? Organization, change and adaptation in the Brazilian Worker's Party, 1980-2012". J ournal of Latin American Studies [online], vol. 46, p. 87-119, 2014. Doi: 10,1017/S0022216X13001831. Acessado em: 3 dez. 2014. 
$\mathrm{RICH}$, J. A. J. "Grassroots bureaucracy: intergovernmental relations and popular mobilization in Brazil's AIDS policy sector". Latin American Politics and Society, Miami, vol. 55, n² 2, p. 1-25, Summer 2013.

SANTILLI, J. Socioambientalismo e novos direitos: proteção jurídica à diversidade biológica e cultural. São Paulo: Editora Peirópolis, 2005.

SCHERLIS, G. "Political appointments and party patronage in Argentina: building parties as governamental networks". In: Anais $21^{\circ}$ Congresso Mundial de Ciência Política, Santiago, Chile, p. 1-25, 2009.

SERAFIM, L. "Participação no governo Lula: as pautas da reforma urbana no Ministério das Cidades (2003-2010)". Tese de Doutorado em Ciências Sociais. Instituto de Filosofia e Ciências Humanas, IFCH/Unicamp, Campinas, 2013.

SILVA, M. K.; OliveiRA, G. L. "A face oculta(da) dos movimentos sociais: trânsito institucional e intersecção Estado-Movimento - uma análise do movimento de economia solidária no Rio Grande do Sul". Sociologias, vol. 13, n² 28, p. 86-125, 2011.

TATAGIBA, L. Relaciones entre movimientos sociales e instituciones políticas: el caso del movimiento de vivienda. In: KoWARICK, L.; MARQUES, E. (orgs.). São Paulo miradas cruzadas: sociedad, política y cultura. Quito: Olacchi, 2011.

TAtagiba, L.; Paterniani, S. Z.; TRIndAde, T. "Ocupar, reivindicar, participar: sobre o repertório de ação do movimento de moradia de São Paulo". Opinião Pública [online], vol. 18, n² 2, p. 399-426, 2012. Disponível em: <http://www.scielo.br/scielo.php?pid=S0104-

62762012000200007\&script=sci_abstract> Acesso em: 5 jun. 2014.

VIOLA, E.; LEIS, H. A evolução das políticas ambientais no Brasil, 1971-1991: do bissetorialismo preservacionista para o multissetorialismo orientado para o desenvolvimento sustentável. In: HogAN, D.; VIEIRA, P. (orgs.). Dilemas socioambientais e desenvolvimento sustentável. Campinas: Editora da Unicamp, 1992.

VIOLA, E.; VIEIRA, P. "Da preservação da natureza e do controle da poluição ao desenvolvimento sustentável: um desafio ideológico e organizacional ao movimento ambientalista no Brasil". Revista de Administração Pública, Rio de Janeiro, vol. 26, n 4, p. 81-104, out.-dez., 1992.

\section{Resumo}

Nomeações políticas no Ministério do Meio Ambiente (2003-2013):

interconexões entre ONGs, partidos e governos

Neste artigo, exploramos mudanças na relação entre movimentos sociais e o governo do Partido dos Trabalhadores pela lente da política de nomeações de cargos de alto escalão no Ministério do Meio Ambiente (MMA) entre 2003 e 2013. Ao analisar as biografias profissionais e políticas de 147 nomeados, identificamos uma diminuição, ao longo do período, de nomeações de atores originários de movimentos sociais, acompanhada por um crescimento de nomeações de servidores públicos. Sugerimos que essa mudança não é somente resultado de transformações das preferências políticas do governo petista. Resulta também de um aumento no número absoluto de funcionários concursados, o que tornou o governo menos dependente, do que era no passado, das capacidades técnicas e políticas presentes na sociedade civil.

Palavras-chave: movimento ambientalista; nomeação de cargos públicos; trajetórias profissionais; Estado; Partido dos Trabalhadores 


\begin{abstract}
Political appointments in Ministry of Environment (2003-2013):

interconnections among NGOs, parties and governments

In this article, we explore the changing relationship between social movements and the Workers' Party government, by looking at appointments to upper echelon positions in the Ministry of the Environment between 2003 and 2013. Our examination of the professional and political biographies of 147 appointees demonstrates that over the period, fewer social movement actors and more public servants were nominated. We suggest that this change did not result only from transformations in the political preferences of the Workers' Party government. It also resulted from an increase in the absolute number of permanent employees, which made the government less dependent than in the past on the technical and political capacities of civil society actors.
\end{abstract}

Keywords: environmental movement; government appointments; professional trajectories; state; Workers' Party

Artigo submetido à publicação em setembro de 2014.

Versão final aprovada em março de 2015. 